\title{
Student Development Services of Kalinga State University
}

\author{
PAULINO P. REYES II \\ Kalinga State University \\ Bulanao, Bulanao Campus \\ Tabuk, Kalinga, Philippines
}

\begin{abstract}
This research assessed the Student Development Services of Kalinga State. It was delimited on the level of implementation of the Student Development Services (SDS) of KSU, and extent of factors on the level of implementation of the Student Development Services (SDS). The study involved the 287 student-leaders who served as respondents and representatives of the student body of the Kalinga State University during the school year 2017-2018. The study made use of the descriptive survey type of research method with a questionnaire that was used to collect the needed data to answer the specific objectives of the study. The student respondents perceived that the student development services of $K S U$ are much implemented as shown by the total average weighted mean of 3.73.There are significant differences in the level of implementation of the student development services of KSU as to institute. There are no significant differences in the level of implementation of the student development services of KSU as to year level. The factors much affect the implementation of the student development services of KSU as perceived by the students with the total average weighted mean of 3.45. There are no significant differences as to factors on the level of implementation of the Student development Services as to institute and year level. Based from the findings and conclusions of the study, the following recommendations are offered; the members of the KSU Alumni Association together with the officers should come up with more programs, activities as well as projects that will bring significant achievements to the association by enlisting the mass participation of its members; KSU should undertake the expansion of its dormitories to provide affordable accommodation to its clientele; KSU Alumni data base should be established to enable graduates of KSU to re-establish connection with their Alma Mater; and an aggressive fund generating project should be conceptualized by the KSU Administration to source out resources for its student development programs.
\end{abstract}

Keywords: Factors, Implementation, Student Development Services

\section{Introduction}

Students development services involve all the activities and services provided for students in schools for the achievement of the educational goals and objectives. They are the non-instructional functions rendered to students to enhance quality learning outcomes and are therefore very important to the efficient and effective functioning of higher institutions. Akinnubi and Kayode (2012) viewed students' personnel services as welfare services provided in educational institutions in order to prevent unnecessary increase in the rate of anti-social activities among the students and to encourage positive thinking and actions that would promote the attainment of their academic pursuit and choices of future career. This definition is all embracing because it takes into account services that reduce students' vices in higher institutions as well as activities that promote, encourage and guide students in their academic work. Students Development Services are aimed at satisfying students' needs. They compliment the normal classroom teaching and facilitate the attainment of the desired educational objectives. Adequate provision and effective management of students' development services make students to behave in a desirable manner that will enhance their academic success while ineffective management of these services may result to undesirable behaviors that can impact negatively on their academic performance.

The role of these student services is influenced by the beliefs and values of the employed staff, by the manner in which the policies are elaborated, by the content of curriculum and services, and by the degree of knowledge regarding the development of the students and the way in which the environment outlines their behavior. In Kalinga State University, there is a need to assess the student development services to see to it whether each service is addressing the needs of its clientele or not. Whatever service to be found not functioning well, it is here where we are to prepare an intervention. We need to do our task as frontline services in order to meet the vision-mission, goals and objectives of our institution and one thing more, we are already working out for the ISO certification of all processes in the university. 
Everything should be in place if possible. We have to straighten and strengthen our poor processes and services. It is into this reason why the research is being conducted. Students could perform well both in their academic and extracurricular activities when their needs have been recognized. The more they can exert efforts to strive more in order to excel when they are served in the institution. This scenario is one bridge to compete globally as cited by Sucliyao (2012).

\section{Conceptual Framework}

Students are considered to be the centre of educative process and learning. It is but proper that in an educational institution, the students should be given full attention To this effect, the services needed by these students should be given an attention. Refinement of the services should be displayed as cited by Alejo (2015)that the personnel of the student services unit should be vigilant enough in providing the needs of every student. Once the student feels that he belongs to the institution, he will feel also that he is worthy to give back his support to his school". It is to this reason why the researcher conducted a research on the student development services of Kalinga State University as the dependent variable; while the independent variables sought to determine the level of implementation of the Student Development Services of Kalinga State University and to determine the extent of factors affecting the implementation of the Student development Services; and the moderator variables are institute and year level.

\section{Statement of the Problem}

The research assessed the implementation of the Student Development Services of Kalinga State University during the school year 2017-2018.

Objectives of the Study;

1. To determine the level of implementation of the Student Development Services of Kalinga State University .

2. Is there a significant difference between the implementation of the various student development services by institute and year level?

3. To determine the extent of factors affecting the implementation of student development services of KSU.

4. Is there a significant relationship between the level of implementation and extent of effect of factors in the implementation of the student development services?
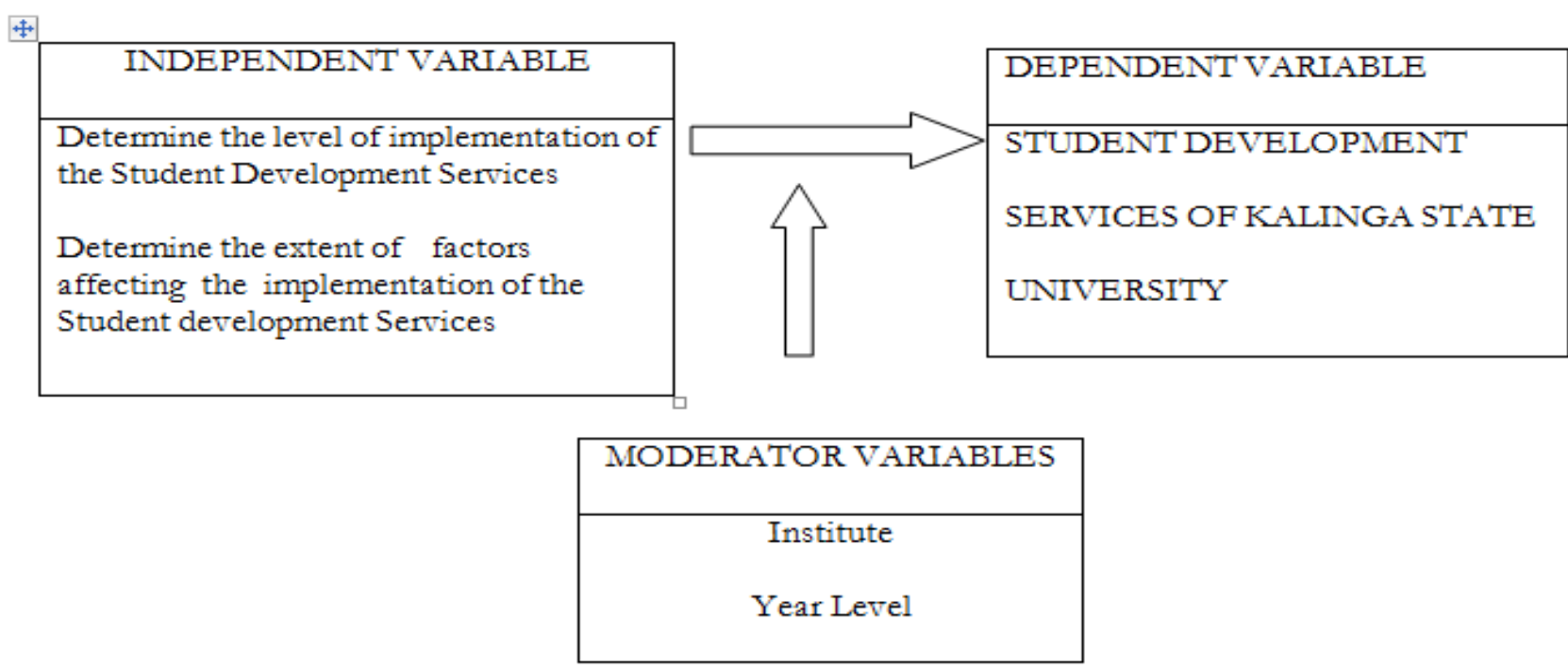

Figure 1: Paradigm of the Study

\section{Research Methodology}

The study made use of the descriptive survey type of research method with a questionnaire that was used to collect the needed data to answer the specific objectives of the study. The study involved the 287 student-leaders who served as respondents and representatives of the student body of the Kalinga State University during the school year 2017-2018.

\section{Results and Discussion}

Level Of Implementation Of The Student Development Services Of KSU 
The table shows that the student respondents perceived that the student development services of KSU are much implemented as shown by the total average weighted mean of 3.73. This much implemented perception is due to the conduct of student orientation activities at the designed to help students adjust to their new environment as well as to inform students of their rights and privileges coupled with their duties and obligations. Sucliyao (2014) found out in his study that much implementation of student services play a vital role in the success of students and the quality of graduates of learning institutions.

The AACCUP Survey instrument also states that a program of student services is an integral part of the institutional planning and operation designed to assist individual-dual student to attain maximum self-realization and to become effective in his social environment. These services must be much implemented to complement the academic program (AACUP Survey Instrument p. 42).

Scholarship is ranked first with an obtained mean of 3.94 or much implemented. Second in rank is "Athletics/Sports" with a mean of 3.92 also much implemented, followed by "Student Enrolment and Admission" with a mean of 3.91, "Health Services" at 3.85; "Guidance Services" with 3.83.

The "Library Services" and Student Affairs Services-Bulanao Campus are tied in sixth with 3.82. Student AffairsDagupan Campus ranked seventh with the weighted mean of 3.65.

The "Socio-Cultural" is eight in rank with a weighted mean of 3.64; "Student Publication" is ranked ninth in the services with a weighted mean of 3.57. All of the means mentioned fall under the much implemented description.

The lowest mean of 3.40 or moderately implemented is obtained by "dormitory services".

The Kalinga State University offers internal (Academic Scholarship, Central Student Government (CSG), Choir, Dance Troupe, KSU Band, Working students, and KSU Employee beneficiaries) and external scholarship grants (Cordillera Green Network, LGU Scholarship, Barangay Scholarship, PDAF, NCIP, ROTC, and others) benefiting one third of the total student population. This explains the high perception of the student-respondents regarding the scholarship services towards student development. Like other high education institution, KSU extends financial assistance to its students in the form of scholarship, activity migrants or study-loan discount. This can be classified as full or partial scholarships. As the name implies, academic scholarships are given in recognition of the students' academic excellence. They cover only tuition fees and do not include board and lodging. Entrance scholarships are extended to freshmen. The recipients of this type of scholarship are high school who graduated as valedictorians or salutatorians of their respective classes.

Likewise, special discounts are given to students under the honour section program and to children of faculty members of employees of the school. Sometimes, family discounts are given to two or more brothers and sisters enrolled in the same institution. Scholarship services are in accordance with the constitutional mandate to initiate scholarship in the arts, sciences, and letters for gifted citizens (www. Scholarship.net)

"Athletics/Sports" with a mean of 3.92 is also perceived as much implemented because one of the hallmarks of student life is sports.

It is expected that the student-respondents perceived the indicators "student enrolment and admission" as much implemented because they have experienced these services during the enrolment or registration period before every semester.

According to Manga(2014), Guidance services are organized curricular activities designed to give systematic aid of students in solving their problems and in making adjustments to various situations which they must meet.

The importance of guidance services cannot be denied. According to Jones ( 2009), guidance is the organization of information by the school about the students and his communities for helping the students learn to make wise decisions concerning the future. The guidance office of KSU offers counselling services, referral services, consultation services, and research and evaluation services.

The student -respondents also perceived the "dormitory services" to be moderately implemented because only Bulanao Campus students can benefit. 
Table 1: Perceptions of the students on the level of implementation of the Student Development Services of KSU $(N=287)$

\begin{tabular}{|c|c|c|c|c|c|c|}
\hline SERVICES & $\begin{array}{l}\text { VMI } \\
(5)\end{array}$ & $\begin{array}{l}\text { MI } \\
(4)\end{array}$ & $\begin{array}{l}\text { MoI } \\
(3)\end{array}$ & $\begin{array}{l}\text { LI } \\
(2)\end{array}$ & $\begin{array}{l}\text { NI } \\
\text { (I) }\end{array}$ & $\begin{array}{l}\text { Wtd. } \\
\text { Mean }\end{array}$ \\
\hline 1. Student enrolment and admission & $\begin{array}{l}(76) \\
380\end{array}$ & $\begin{array}{l}128 \\
(512)\end{array}$ & $\begin{array}{l}68 \\
(204)\end{array}$ & $\begin{array}{l}10 \\
(120)\end{array}$ & $\begin{array}{l}5 \\
(5)\end{array}$ & 3.91 \\
\hline $\begin{array}{l}\text { 2. Student Development Services- } \\
\text { Dagupan }\end{array}$ & $\begin{array}{l}67 \\
(335)\end{array}$ & $\begin{array}{l}130 \\
(520)\end{array}$ & $\begin{array}{l}66 \\
(198) \\
\end{array}$ & $\begin{array}{l}18 \\
(36)\end{array}$ & $\begin{array}{l}6 \\
(6)\end{array}$ & 3.82 \\
\hline $\begin{array}{l}\text { 3. Student Development Services- } \\
\text { Bulanao }\end{array}$ & $\begin{array}{l}43 \\
(215)\end{array}$ & $\begin{array}{l}142 \\
(568)\end{array}$ & $\begin{array}{l}74 \\
(222)\end{array}$ & $\begin{array}{l}15 \\
(30)\end{array}$ & $\begin{array}{l}13 \\
(13)\end{array}$ & 3.65 \\
\hline 4. Health Service & $\begin{array}{l}87 \\
(415)\end{array}$ & $\begin{array}{l}98 \\
(392)\end{array}$ & $\begin{array}{l}79 \\
(237)\end{array}$ & $\begin{array}{l}18 \\
(36)\end{array}$ & $\begin{array}{l}5 \\
(5)\end{array}$ & 3.85 \\
\hline 5. Guidance Service & $\begin{array}{l}71 \\
(355)\end{array}$ & $\begin{array}{l}125 \\
(500)\end{array}$ & $\begin{array}{l}68 \\
(204) \\
\end{array}$ & $\begin{array}{l}18 \\
(36)\end{array}$ & $\begin{array}{l}5 \\
(5)\end{array}$ & 3.83 \\
\hline 6. Scholarship & $\begin{array}{l}130 \\
(650)\end{array}$ & $\begin{array}{l}101 \\
(404)\end{array}$ & $\begin{array}{l}13 \\
(39)\end{array}$ & $\begin{array}{l}16 \\
(32)\end{array}$ & $\begin{array}{l}7 \\
(7)\end{array}$ & 3.94 \\
\hline 7. Socio-cultural Services & $\begin{array}{l}57 \\
(285)\end{array}$ & $\begin{array}{l}111 \\
(444)\end{array}$ & $\begin{array}{l}83 \\
(249)\end{array}$ & $\begin{array}{l}31 \\
(62)\end{array}$ & $\begin{array}{l}5 \\
(5)\end{array}$ & 3.64 \\
\hline 8. Library Service & $\begin{array}{l}74 \\
(370)\end{array}$ & $\begin{array}{l}121 \\
(484)\end{array}$ & $\begin{array}{l}63 \\
(189)\end{array}$ & $\begin{array}{l}23 \\
(46)\end{array}$ & $\begin{array}{l}6 \\
(6)\end{array}$ & 3.82 \\
\hline 9. Canteen Services & $\begin{array}{l}52 \\
(260)\end{array}$ & $\begin{array}{l}107 \\
(428)\end{array}$ & $\begin{array}{l}89 \\
(267)\end{array}$ & $\begin{array}{l}30 \\
(60)\end{array}$ & $\begin{array}{l}9 \\
\text { (9) }\end{array}$ & 3.57 \\
\hline 10. Dormitory Services & $\begin{array}{l}48 \\
(240)\end{array}$ & $\begin{array}{l}92 \\
(368)\end{array}$ & $\begin{array}{l}91 \\
(273)\end{array}$ & $\begin{array}{l}39 \\
(78)\end{array}$ & $\begin{array}{l}17 \\
(17)\end{array}$ & 3.40 \\
\hline 11. Student Publication & $\begin{array}{l}48 \\
(240)\end{array}$ & $\begin{array}{l}121 \\
(484)\end{array}$ & $\begin{array}{l}82 \\
(246) \\
\end{array}$ & $\begin{array}{l}29 \\
(58) \\
\end{array}$ & $\begin{array}{l}7 \\
(7) \\
\end{array}$ & 3.61 \\
\hline 12. Alumni Services & $\begin{array}{l}50 \\
(250)\end{array}$ & $\begin{array}{l}91 \\
(364)\end{array}$ & $\begin{array}{l}100 \\
(300)\end{array}$ & $\begin{array}{l}36 \\
(72)\end{array}$ & $\begin{array}{l}10 \\
(10)\end{array}$ & 3.47 \\
\hline 13. Athletic/Sports & $\begin{array}{l}84 \\
(420)\end{array}$ & $\begin{array}{l}122 \\
(488)\end{array}$ & $\begin{array}{l}56 \\
(168)\end{array}$ & $\begin{array}{l}23 \\
(46)\end{array}$ & $\begin{array}{l}2 \\
(2)\end{array}$ & 3.92 \\
\hline TAWM & & & & & & 3.73 \\
\hline
\end{tabular}

The table below shows the implementation of the student development services as to Institute. Based on the result, the F-computed ratio of 9.39 is greater than the tabular value of 3.32 at .05 level of significance. To this effect, the null hypothesis which states that there are no significant differences between the implementation of the various student development services as to Institute is rejected. Therefore, there are significant differences between the implementation of the various student development services as to Institute.

Table 2. Implementation of the Student Development Services of KSU as to Institute

\begin{tabular}{|l|l|l|l|}
\hline Institute & Mean & Rank & F-ratio \\
\hline IBAE & 3.70 & 4 & \\
\hline IAS & 3.69 & 5 & \multirow{3}{*}{9.39} \\
\hline IAF & 3.75 & 3 & \\
\hline IMEAT & 3.80 & 1 & \\
\hline ITE & 3.77 & 2 & \\
\hline IHS & 3.57 & 6 & \\
\hline TAWM & 3.73 & & \\
\hline
\end{tabular}

\section{F.05=3.32}

Decision: Significant/HO rejected

The table below shows the implementation of the Student development Services as to Year Level.

If we are to look at the table below, the F-computed ratio of 2.78 is much lower than the tabular value of 3.32 at .05 level significance. This shows that the null hypothesis which states that there are no significant differences between the implementation of the various student development services as to Year level is accepted. Thus, there are no significant differences between the implementation of the various student development services as to Year level. 
Table 3. Implementation of the Student development Services as to Year Level

\begin{tabular}{|l|l|l|l|}
\hline Year Level & Mean & Rank & F-ratio \\
\hline First Year & 3.80 & 1 & \\
\cline { 1 - 1 } Second Year & 3.77 & 2 & \\
\hline Third Year & 3.69 & 4 & \multirow{2}{*}{2.78} \\
\cline { 1 - 3 } Fourth Year & 3.64 & 5 & \\
\cline { 1 - 2 } & 3.73 & 3 & \\
\hline
\end{tabular}

\section{F.05=3.32}

Decision: Significant/HO accepted

The table below shows that the factors much affect the implementation of the student development services of KSU as perceived by the students with the total average weighted mean of 3.45. Six indicators fall under the much affect descriptions namely "financial aspects limit the effective implementation of the student development services of the school" with the average mean of 3.69, "there is no cooperation of both students and faculty in the implementation of the SDS" at 3.68. As stated in the AACCUP survey (2000), the physical plant and facilities and of an educational institution allows for the conduct of activities that promote development such as sports activities, stage performance, concerns, seminars, trainings and other social gatherings (ADB Educational Report, 2011).

The school provides the needed facilities, equipment and materials that are greatly needed in the implementation of the student development services at 3.59, the availability of trainers or coaches and experts that will rigorously train and guide the students for national competitions are inadequate at 3.55, schedule of classes deprive students to participate in development programs at 3.50, selection of members for the different activities of the student development services is limited to few at 3.49, and linkages to other student development services are inadequate at 3.43. The lowest mean of 2.68 is obtained by "the information dissemination to the community on the student development services of the school is limited The respondents stated that although information dissemination to the community about student development services is important to develop and sustain harmonious relations with its service area, its effect on the implementation of student development services is to low extent, Students argued to the instructors that the information dissemination to the community will only gain their support and enhance their sense of belonging but it will not affect the level of implementation of the student development services since it is not the school itself that ultimately directs, manages and coordinates the implementation of the student development services. This is related to the study of Akinnubi (2009) on the extent of involvement of stakeholders in the implementation of student development services wherein community involvement was perceived that has less effect development programs.

Table 4: Perceptions of the Student-Respondents on the Extent of factors affecting the Implementation of the Student development Services of KSU ( $\mathbf{N = 2 8 7})$

\begin{tabular}{|c|c|c|c|c|c|c|}
\hline Indicators & $\begin{array}{l}\text { VMA } \\
(5)\end{array}$ & $\begin{array}{l}\text { MA } \\
(4)\end{array}$ & $\begin{array}{l}\text { MoOA } \\
\text { (3) }\end{array}$ & $\begin{array}{l}\mathbf{L A} \\
(2)\end{array}$ & $\begin{array}{l}\text { NA } \\
(1)\end{array}$ & $\begin{array}{l}\text { Wtd. } \\
\text { Mean }\end{array}$ \\
\hline $\begin{array}{l}\text { 1. Financial aspects limit the effective } \\
\text { implementation of the student development services } \\
\text { of the school. }\end{array}$ & $\begin{array}{l}51 \\
(255)\end{array}$ & $\begin{array}{l}127 \\
(508)\end{array}$ & $\begin{array}{l}84 \\
(252)\end{array}$ & $\begin{array}{l}19 \\
(38)\end{array}$ & $\begin{array}{l}6 \\
(6)\end{array}$ & 3.69 \\
\hline $\begin{array}{l}\text { 2. There is no cooperation of both students and } \\
\text { faculty in the implementation of the SDS. }\end{array}$ & $\begin{array}{l}69 \\
(345) \\
\end{array}$ & $\begin{array}{l}101 \\
(404)\end{array}$ & $\begin{array}{l}82 \\
(246) \\
\end{array}$ & $\begin{array}{l}25 \\
(50) \\
\end{array}$ & $\begin{array}{l}10 \\
(10)\end{array}$ & 3.68 \\
\hline $\begin{array}{l}\text { 3. The school facilities, equipment, and materials } \\
\text { that greatly needed in the implementation of the SDS } \\
\text { are inadequate. }\end{array}$ & $\begin{array}{l}51 \\
(255)\end{array}$ & $\begin{array}{l}101 \\
(404)\end{array}$ & $\begin{array}{l}108 \\
(324)\end{array}$ & $\begin{array}{l}20 \\
(40)\end{array}$ & $\begin{array}{l}7 \\
(7)\end{array}$ & 3.59 \\
\hline $\begin{array}{l}\text { 4. The availability of trainers or coaches and experts } \\
\text { that will rigorously train and guide the students for } \\
\text { national competitiveness are inadequate. }\end{array}$ & $\begin{array}{l}53 \\
(265)\end{array}$ & $\begin{array}{l}99 \\
(396)\end{array}$ & $\begin{array}{l}96 \\
(288)\end{array}$ & $\begin{array}{l}30 \\
(60)\end{array}$ & $\begin{array}{l}9 \\
(9)\end{array}$ & 3.55 \\
\hline $\begin{array}{l}\text { 5. Selection of members for the different activities is } \\
\text { limited to few. }\end{array}$ & $\begin{array}{l}39 \\
(195)\end{array}$ & $\begin{array}{l}104 \\
(416)\end{array}$ & $\begin{array}{l}109 \\
(327)\end{array}$ & $\begin{array}{l}29 \\
(58)\end{array}$ & $\begin{array}{ll}6 \\
(6)\end{array}$ & 3.49 \\
\hline $\begin{array}{l}\text { 6. Information dissemination to the community on } \\
\text { the student development services of the school is } \\
\text { limited. }\end{array}$ & $\begin{array}{l}4 \\
(20)\end{array}$ & $\begin{array}{l}33 \\
(132)\end{array}$ & $\begin{array}{l}106 \\
(318)\end{array}$ & $\begin{array}{l}133 \\
(266)\end{array}$ & $\begin{array}{l}11 \\
(11)\end{array}$ & 2.68 \\
\hline $\begin{array}{l}\text { 7. Linkages to other student development services } \\
\text { are inadequate. }\end{array}$ & $\begin{array}{l}34 \\
(170)\end{array}$ & $\begin{array}{l}101 \\
(404)\end{array}$ & $\begin{array}{l}110 \\
(330)\end{array}$ & $\begin{array}{l}37 \\
(74)\end{array}$ & $\begin{array}{l}5 \\
(5)\end{array}$ & 3.43 \\
\hline $\begin{array}{l}\text { 8. Schedule of classes deprives students to } \\
\text { participate in development programs. }\end{array}$ & $\begin{array}{l}38 \\
(190) \\
\end{array}$ & $\begin{array}{l}105 \\
(420)\end{array}$ & $\begin{array}{l}109 \\
(327) \\
\end{array}$ & $\begin{array}{l}32 \\
(64)\end{array}$ & $\begin{array}{l}3 \\
(3) \\
\end{array}$ & 3.50 \\
\hline TAWM & & & & & & 3.45 \\
\hline
\end{tabular}

Fig 5:

Based on the table below, the computed $F$ ratio of 2.68 is much lower than the tabular value of 4.96 at .05 level of significance. This means that the null hypothesis which states that there are no significant relationships between the level of implementation and extent of factors affecting the student development services is accepted. 
Thus, there are no significant relationships between the level of implementation and extent of factors affecting the student development services as to Institute.

Table 5. Extent of Factors Affecting the Implementation of the Objectives of the Student development $t$ Services of KSU as to Institute.

\begin{tabular}{|c|c|c|c|}
\hline Institute & Mean & Rank & F-ratio \\
\hline IBAE & 3.40 & 5 & \multirow{7}{*}{2.68} \\
\hline IAS & 3.35 & 6 & \\
\hline IAF & 3.52 & 1 & \\
\hline IMEAT & 3.50 & 2 & \\
\hline ITE & 3.49 & 3 & \\
\hline IHS & 3.46 & 4 & \\
\hline TAWM & 3.45 & & \\
\hline
\end{tabular}

F.05=4.96

Decision: Not Significant/HO accepted

The table below presents the factors affecting the level of implementation of the objectives of the Student development $\mathrm{t}$ Services of KSU as to Year Level.

It is gleaned in the table that the computed F-ratio of 3.09 is much lower than the tabular value of 4.96 at .05 level of significance. To this effect, the null hypothesis which stated that there are no significant relationships between the level of implementation and extent of factors affecting the student development services as to Year level is accepted. Therefore, there are no significant relationships between the level of implementation and extent of factors affecting the student development services as to Year level.

Table 5. Extent of Factors Affecting the level of Implementation of the Objectives of the Student Development Services of KSU as to Year Level

F. $05=4.96$

\begin{tabular}{|l|l|l|l|}
\hline Year Level & Mean & Rank & F-ratio \\
\hline First Year & 3.50 & 1 & \\
\cline { 1 - 3 } Second Year & 3.47 & 2 & \multirow{2}{*}{3.09} \\
\hline Third Year & 3.42 & 3 & \\
\cline { 1 - 3 } Fourth Year & 3.40 & 4 & \\
\cline { 1 - 2 } & 3.45 & \multicolumn{2}{|c|}{} \\
\hline
\end{tabular}

\section{Conclusions and Recommendations}

Based from the findings of the study, the following conclusions are drawn: the Student Development Services of KSU were much implemented having a total average weighted mean of 3; there are significant differences in the level of implementation of the student development services as to institute but as to year level, there are no significant differences in the level of implementation of the student development services. the Extent of Effect of factors much affect the level of implementation of the Student Development Services with a total average weighted mean of 3.45; there are no significant relationships between the level of implementation and the extent of the factors affecting the student development services as to institute and there are no significant relationships between the level of implementation and the extent of the factors affecting the student development services as to year level.

As to the result of findings, the researcher came up with the following recommendations; the dormitory chairpersons of both male and ladies dormitory may update their annual plans and programs for the welfare of the dorm occupants; the members of the KSU Alumni association together with the officers may come up with more programs, activities as well as projects that will bring significant achievements to the association by enlisting the mass participation of its members.; A KSU Alumni data base should be established to enable graduates of KSU to re-establish connection with their Alma Mater and an aggressive fund generating project should be conceptualized by the KSU administration to source out resources for its student development programs.

\section{References}

AACCUP Survey Instrument 2000

Alejo, Grace (2015). "The Student Development Services of Quirino State University", unpublished Dissertation, Quirino State University, Diffun, Quirino

Audin and Davy, 2003. The Role of Student Services in the Improving of Student Experience in Higher Education. 
Akinnubi, O. P \& Kayode, D. J. (2012). Student personnel services and students' behaviors in University of Ilorin. Global Journal of Applied

Sciences, Management and Social Sciences (1). Available online: www.gojemss.com. Retrieved $21^{\text {st }}$ March, 2014 Jones (www.arthur. Guidance. Jone 2009)

Manga, S. D., Goshe, M. D. \& Nakazalle, N. U. (2014). Management of student personnel services as a strategy for institutionalizing peace culture in Tertiary Institutions in Nigeria. Paper presented at the 33rdAnnual National Conference of the Nigerian Association of Educational Administration and Planning (NAEAP). Abuja. Oct. 14,2014

Rona F. Flippo, David C. Caverly, Handbook of College Reading and Study Strategy Research: "Student development Centre"

Student Development in Higher Education: Theories, Practices, and Future Directions. Cincinnati: ACPA, 1980. Newstrom, 1976

Sucliyao, Roderick B., "The Implementation of School Policies on Student Discipline in St. Theresita's High School, Pinukpuk, Kalinga

www.arthuir.guidance.worker.2006

www.Irajgordon.teacherguidance.worker.2005

www.guidance.services.

www.kzoo.edu/stude/golas.html). 